\title{
DIE ZIELE
}

der

\section{LEUCHTTECHNIK.}

Von

\section{Professor Dr. Otto Lummer,}

Dozent an der Univeraităt Berlin,

Mitglied der Physikalisch-Technischen Reichsanstalt.

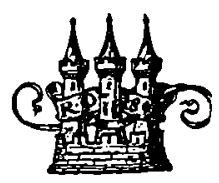

München und Berlin.

Druck und Verlag von R. Oldenbourg.

1903. 
